\title{
VAGINAL DRUG ABSORPTION IN THE RHESUS MONKEY: BIOAVAILABILITY METHOD AND ASSESSMENT OF ESTROGENS
}

\author{
J.Y. PARK, M. LANGWORTHY, C.R. BEHL, W.I. HIGUCHI, G.L. FLYNN and N.F.H. HO \\ College of Pharmacy, The University of Michigan, Ann Arbor, Mich. 48109 (U.S.A.) \\ (Received June 29th, 1978) \\ (Accepted July 14th, 1978)
}

\section{SUMMARY}

Novel experimental and theoretical methods in evaluating the systemic bioavailability of estrogens delivered via the vaginal route have been developed. The approaches were demonstrated for estrone and estradiol in the rhesus monkey. These newly diveloped techniques have made it possible to quantify first pass vaginal membrane metabolism for estrone and for estradiol and to distinguish this process from peripheral tissue metabolism. This was achieved by obtaining steady-state blood levels of the steroids and all significant metabolites resulting from identical zero-order infusion rates of the steroid by the vaginal and intravenous routes. Comparison of the blood levels gave rapid estimations of bioavailability. The modeling of the steady-state situation and quantification of the kinetic parameters were employed such that differences in blood levels from vaginal and intravenous drug infusion mirrored the membrane transport and metabolic events. Membrane metabolism of infused estrone and estradiol reduced the blood levels of these steroids by about 55 and $61 \%$, respectively, of that expected in the absence of membrane metabolism.

About $45 \%$ of vaginally administered estrone appeared directly in the blood as estrone and $9 \%$ as estradiol and $46 \%$ as total conjugates. The dominant route of membrane metabolism of estrone was estrone conjugation rather than reduction to estradiol. When estradiol was infused vaginally, $26 \%$ estradiol appeared in the blood and $35 \%$ as estrone and $39 \%$ as total conjugates; the dominant route of metabolism was the ixidation to estrone and not estradiol conjugation.

\section{INTRODUCTION}

The vaginal route of administration of drugs is a viable alternative to oral therapy for select contraceptive compounds and possibly other therapeutics. Further, vaginal drug delivery has exploitable advantages relative to other modes of administration in the areas 
of bioavailability and controlled drug delivery. This belief has its basis in the demonstrated clinical utility of vaginally administered progestational steroids (Mishell et al., 1972; Kirton et al., 1973; Johansson et al., 1975) and prostaglandins (Nuwayscr and Williams, 1974; Fried et al., 1973) as well as other drugs such as the penicillins (Goldberger et al., 1947) and sulfonamides (Carrington et al., 1944). Also, it has been suggested that pharmacological effects might be regionalized or localized vaginally, a most desirable feature for contraceptive drugs. This is viewed as a remote possibility unless there is significant drug migration into the uterus. However, other realistic and compelling reasons to take this route of administration for contraceptive drugs most seriously exist. The vaginal cavity has an extensive surface area, possibly as much as $100-150 \mathrm{~cm}^{2}$ in the adult human female, and it is adequately accessible for self-administration purposes. Moreover, given the widespread use of tampons, pessaries, diaphragms and vaginal suppositories, it is obvious that relatively large, solid objects can be inserted in the vaginal vault without undue discomfort to the user. Thus, the vagina is a promising compartment for the use of sophisticated controlled-release devices. Indeed, several prototype device systems have proven effective. The vaginal route thereby provides for continuous, programmed administration of therapeutics, avoiding the spiking of blood levels associated with the use of oral dosage forms which are administered as discrete, discontinuous doses. Another feature of this route of administration which may have a particular significance for the natural contraceptive steroids - $\beta$-estradiol, estrone and progesterone - is that the vagina is serviced by a different arterio-venous plexus than the smail intestine and compounds entering the circulatory system are distributed throughout the body prior to entering the liver. Liver first pass effects can be avoided. One can also speculate that the vaginal mucosa is metabolically different than the mucosa of the small intestine and drugs, which are inactivated in the small intestine, may escape serious mucosal metabolism concurrent with absorption by the vaginal route. Both of the latter factors, liver first pass effects and mucosal metabolism, have been put forth as reasons why the natural contraceptive steroids are poorly bioavailable orally.

The realization of the full potential and the defining of the limitations of the vaginal route of administration for contraceptive purposes and other therapeutic purposes are hindered by a general ignorance of the membrane properties of this tissue. One must know in quantitative terms how permeable and metabolically active the tissue is in order to administer drugs in adequate total amounts, in adequate concentrations and on an adequate dosing schedule to obtain clinically desired endpoints, regardless of the type of dosage system under consideration.

Recently, the methodology in determining vaginal drug absorption in the female rhesus monkey (Owada et al., 1977) was developed from prototype methods and procedures for studying vaginal absorption in the rabbit doe (Yotsuyanagi et al., 1975). The rabbit lacks a sexual cycle while the rhesus monkey is a sexually cyclical animal closely approximating the human female in many' respects. Drug absorption was usually determined by following disappearance kinetics in a closed perfusion system. Here, the surface area of the vagina was fixed by the use of rib-cage cells designed for intravaginal insertion through the vulval orifice and individualized to fit the vaginal dimensions of the monkey. Vaginal permeability studies in the rabbit doe with n-alkanols (Hwang et al., 1976), n-alkanoic acids (Hwang et al., 1977) and steroids (Flynn et al., 1976) to characterize 
the membrane and with steroid-silicone rubber matrix (Flynn et al., 1976) have been extended to similar studies in the monkey *.

The objective of this present study is to assess the kinetic fate of natural contraceptive estrogens, specifically estrone and estradiol, during the course of their vaginal absorption. The notable results will be the quantitative estimation of the bioavailability of vaginally administered estrogens in the blood for the first time and the development of novel experimental and theoretical approaches in achieving the objective.

The degree to which a membrane (or tissue) metabolizes a substrate in its diffusive course through the rnembrane can be estimated by either assessing the membrane's capacity for bioconversion directly using tissue homogenates or other membrane destructive preparations in vitro or by examining the input and output streams of the living membrane in the courie of the permeation process. Of the two choices, the latter is by far the more relevant as it puts the kinetics of the bioconversion in perspective when considered with kinetics of transport. The biosynthesis of membrane permeable reaction products within the membrane during a perfusion experiment in which the membrane external surface is bathed with a solution of the permeant will lead to a net efflux of the enzymatic by-products back into the donor solution as well as into the general circulation of the animal. The relative amounts of enzymatic by-products passing in these opposite directions will be determined by the 'effective depth' of the enzyme in the tissue and its distribution in the diffusional field. Close proximity of the enzyme to the perfusate bathed surface will result in a measureable build-up of by-products in the perfused solution via back-diffusion providing they are nembrane permeable. Conversely, localization of the enzyme near the tissue microcirculation will result in the systemic appearance of the bulk of the reaction products with little back-diffusic n into the perfused solution. Uniform distribution of enzyme will be seen as a greater back-diffusion than forwarddiffusion of by-product in the course of a transport experiment due to the influence of the substrate gradient on the rate of reaction at various tissue depths. In most cases where membrane permeable by-products are a significant percentage of the substrate uptake by the membrane, measurable concentrations of products will be found in the perfusate. Thus, the back-diffusion of metabolites provides a means of indirectly following the course of membrane metabolism and is unambiguous proof that the membrane is metabolically significantly active within the time frame of the absorption process.

Additional insights can be gained into the enzymatic processes in the membrane by inhibiting the reaction either by overloading the system with substrate (concentration effects) or by co-administering an inhibitor with the capacity to permeate the membrane and stop the reaction. In terms of drug delivery, saturability of the enzyme process may lend itself to manipulating the applied concentration to minimize the undesirable reaction. Since saturation of the process should be easier the closer the enzymes are to the external surface, due to gradient effects, the ease of forcing the enzyme reaction into the zero-order condition provides a clue to the location of the enzymes in the membrane as well as information concerning the enzyme system capacity. The influences of inhibitors on the enzymatic reactions can be similarly enlightening and may additionally suggest

\footnotetext{
* Manuscripts in preparation on vaginal absorption in rhesus monkey of $n$-alkanols, $n$-alkanoic acids, estrogens, progest trone and inplanted steroid-silicone rubber vaginal devices.
} 
ways to facilitate absorption of intact drug when membrane metabolism is significant.

The general means of evaluating the extent of coniugative metabolism involves analyzing the efflux of polar metabolites into the central compartment or blood stream or in the membrane wall of the animal. Numerous prototype experiments of this sort have been performed with a diverse group of substrate permeants; the latter type of experiment involving measurements on the membrane tissue itself is of course dest ructive and requires animal sacrifice. Diczfaluisy et al. (1961), noted the in vivo conversion of estriol to conjugated forms by examing estriol-challenged normal human intestinal tissue which was removed surgically after tine estriol exposure along with adjacent cancerous tissue. They also cannulated the venous effluent of the gastrointestinal section exposed to estriol and found significant fractions of the steroid entering the blood to be in conjugated forms. Later, Diczfalusy et al. (1962) administered $\beta$-estradiol to humans and examined the venous blood of the vasculature of the intestinal wall and the intestinal wall itself for formed compounds. In this case there was also extensive conjugation and the conjugated form was estrone glucuronide, which suggests that two separate metabolic processes were at work in the membrane: oxidation and conjugation.

Srrith et al., (1963) studied the conversion of $\beta$-estradiol in the intestine using everted sacs of rat intestine and found that the oxidation of $\beta$-estradiol precedes conjugation of the steroid to the glucuronide. Stone and Martin (1965) showed that in the mouse vagina estrone is converted to $\beta$-estradiol, by evaluating the concentrations of the respective species in vaginal tissue as a function of time. In a particularly elegant series of experinents involving evaluation of lumenal changes, tissue changes and blood changes, Meli it al. (1968), have further elaborated the metabolic processes affecting the estrogens in the small intestine (in vivo rat) and rave demonstrated that $\beta$-estradiol and estrone are handled very differently in this tissue although both were substantially modified in the iransport process. Oxidation of $\beta$ estradiol to estrone apparently occurs with facility but the reverse reduction is essentially non-existent. Conjugation was extensive for both steroids. Nienstedt and Hartiala (1969) have developed evidence which suggests that the fate of progesterone may be very different from that of the estrogens. They found significanî metabolism of this steroid by monitoring the effluent venous plasma of the small intestine of the dog. The metabolism was primarily one of oxidation to more polar nonelectrolytes and only trace conjugation was noted.

Barr and Riegelman (1970) working with rabbits in vivo and in vitro rabbit intestinal sacs, showed this membrane to be able to extensively conjugate salicylamide during its transport. They also collected venous blood from the closed loop intestinal preparation (living animal) and based their conclusions concerning metabolism on the percent conjugate form in this milieu. These studies were particularly elegant and are noteworthy because they were able to demonstrate, via a lumenal solution concentration dependency of the conjugation, that the enzyme system was saturable. The essential conclusions in the live animal preparation were confirmed with independent everted gut experiments. All these experiments illustrate the importance of following the membrane processes on the blood side of the membrane or in the tissue itself. In most of these cases membrane metabolism would not have been evident if only the cavital solution concentration (solution instilled into the lumen of the intestine or the mucosal side of the membrane in the everted sac technique) were followed. 
The present studies involve an assessment of the metabolic potentialities of the vaginal route of administration by a novel experimental approach developed in the course of determining the bioavailabilities of estradiol and estrone through the vaginal mucosa. Experiments have been routinely performed in these laboratories involving the steadystate uptake of perfused drug from solutions brought into direct contact with the vaginal surface. However, such drug uptake studies could be misleading as a meaure of systemic input due to metabolic effects occurring within the membrane itself. It is obvious, therefore, that the quantitative determination of the overall pharmacokinetics must include an assessment of the metabolic consequences of the vaginal wal' and its impact on the appearance of the drug and metabolites in the blood. The unique tactical approach taken here involves comparing the peripheral blood concentrations of administered estrogen and major metabolites in the steady-state from zero-order vaginal infusion with the same parameters obtained by zero-order intravenous infusion at a rate equaling the vaginal infusion rate. Differences in species profiles would then reflect metabolic first pass events in the vaginal membrane. Similarity in species profiles is indicative of a low order of metabolic activity.

The expected steady-state species profiles for the blood obtained by zero-order infusion via the vaginal and intravenous routes offer: (a) the advantage for rather simple pharmacokinetic modeling, and (b) the condition whereby the vaginal membrane tissue concentrations are in equilibrium with the peripheral blood-tissue compartment. Importantly, while the pharmacokinetic scheme and, subsequently, the estimation of the rate constants in the external blood-tissue compartment may be model-dependent, the recycling of these constants to factor out the differences in the blood profiles, resulting from the vaginal and intravenous administration of the steroid, will mirror the transport and metabolic events in the vaginal membrane on a quantitative basis that is modelindependent.

In practice, the achierernent of the objectives depends largely upond the successful minimization of the variability of the assay methods employed, including procedural artifacts, and minimization of day-to-day biological variation in the monkeys. The first problem has been solved through the use of quantitative TLC procedures for the separation of the radiolabeled estrogens anci major metabolites coupled with liquid scintillation counting of the isotopic label. The other problems have been dealt with by utilizing the following cross-over experimental scheme:

(a) zero-order intravenous infusion of a 50:50 mixturs of estrone and estradiol in solution, both steroids having a different isotopic label (for example, $\left[{ }^{14} \mathrm{C}\right]$ estrone and $\left[{ }^{3} \mathrm{H}\right]$ estradiol and vice versa).

(b) simultaneous zero-order administration of $\left[{ }^{14} \mathrm{C}\right]$ estradiol by the intravenous route and $\left[{ }^{3} \mathrm{H}\right]$ estradiol vaginally.

(c) simultaneous zero-order infusion of $\left[{ }^{14} \mathrm{C}\right]$ estrone intravenously and $\left[{ }^{3} \mathrm{H}\right]$ estrone vaginally.

The zero-order vaginal and intravenous infusion rates were made as equal as procedurally possible. While the use of a syringe purnp to obtain constant intravenous delivery 
rates is conventional, the hourly replacement of fresh drug perfusion solution in the vagina to get an essentially zero-order trans-membrane infusion rate is novel.

\section{THEORY}

The theoretical basis for the experimental approach taken here to assess the extent of membrane metabolism and the rate of transport of vaginally administered estrogen from the membrane into the blood will be developed here by considering two cases. The first case considers the zero order infusion rate of a mixture of estrone and estradiol, each steroid having a different isotopic label, and the steady-state plasma lsvel of these steroids and their metabolites. The second case accounts for the zero-order vaginal infusion rate of either estrene or estradiol and the resulting steady-state plasma levels of the steroid in question and its metabolites. In both cases the zero-order infusion rates are equal. By comparing the plasma levels and pharmacokinetic rate constants, the effect of the membrane on the bioavailability of vaginally administered estrogens is quantified. The theoretical approach taken here is different from the approach taken by Pang and Gillette (1978) who related the area under the blood level curve and the route of administration of drugs and their precursors for evaluating sites and pathways of metabolism.

Case I: Zero-order intravenous infusion of estrone and estradiol and their steady-state plasma levels

A simple pharmacolinetic model is shown in Scheme 1. First-order kinetic processes and rapid equilibrium between blood and other tissue compartments are assumed here. The steroids are eliminated essentially as the sulfate and glucuronide conjugates (Migeon et al., 1959; Howard et al., 1969). The pharmacokinetics at steady-state for estrone and estradiol are described below.

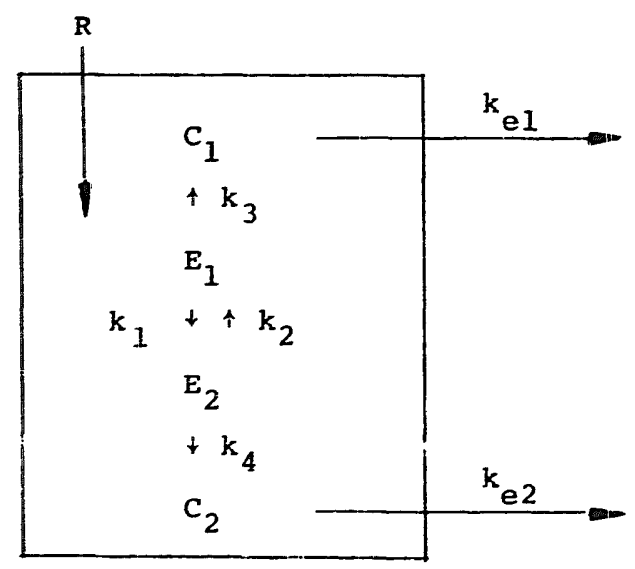

Scheme 1. Zero-order intravenous infusion of estrone and estradiol and pharmacokinetic processes in a one compartment blood-tissue model. 
(a) Steady state pharmacokinetic expressions following zero-order intravenous infusion of estrone

$\frac{d\left(E_{1}\right)_{S}}{d t}=R-k_{1}\left(E_{1}\right)_{S}+k_{2}\left(E_{1}\right)_{S}-k_{3}\left(E_{1}\right)_{S}=0$

$\frac{\mathrm{d}\left(\mathrm{E}_{2}\right)_{\mathrm{S}}}{\mathrm{dt}}=\mathrm{k}_{1}\left(\mathrm{E}_{1}\right)_{\mathrm{S}}-\mathrm{k}_{2}\left(\mathrm{E}_{2}\right)_{\mathrm{S}}-\mathrm{k}_{4}\left(\mathrm{E}_{2}\right)_{\mathrm{S}}=0$

$\frac{\mathrm{d}\left(\mathrm{C}_{1}\right)_{\mathrm{S}}}{\mathrm{dt}}=\mathrm{k}_{3}\left(\mathrm{E}_{1}\right)_{\mathrm{S}}-\mathrm{k}_{\mathrm{el}}\left(\mathrm{C}_{1}\right)_{\mathrm{S}}=0$

$\frac{\mathrm{d}\left(\mathrm{C}_{2}\right)_{\mathrm{S}}}{\mathrm{dt}}=\mathrm{k}_{4}\left(\mathrm{E}_{2}\right)_{\mathrm{S}}-\mathrm{k}_{\mathrm{e} 2}\left(\mathrm{C}_{2}\right)_{\mathrm{S}}=0$

$(A)=\left(C_{1}\right)_{S}+\left(C_{2}\right)_{S}$

(b) Steady-state pharmacokinetic expressions following zero-order intravenous infusion of $\beta$-estradiol

$$
\begin{aligned}
& \frac{d\left(E_{1}\right)_{D}}{d t}=-k_{1}\left(E_{1}\right)_{D}+k_{2}\left(E_{2}\right)_{D}-k_{3}\left(E_{1}\right)_{D}=0 \\
& \frac{d\left(E_{2}\right)_{D}}{d t}=R+k_{1}\left(E_{1}\right)_{D}-k_{2}\left(E_{2}\right)_{D}-k_{4}\left(E_{2}\right)_{D}=0 \\
& \frac{d\left(C_{1}\right)_{D}}{d t}=k_{3}\left(E_{1}\right)_{D}-k_{e 1}\left(C_{1}\right)_{D}=0 \\
& \frac{d\left(C_{2}\right)_{D}}{d t}=k_{4}\left(E_{2}\right)_{D}-k_{e 2}\left(C_{2}\right)_{D}=0 \\
& (B)=\left(C_{1}\right)_{D}+\left(C_{2}\right)_{D}
\end{aligned}
$$

The plasma concentrations in $\mu \mathrm{g} / \mathrm{ml}$ are:
$\left(E_{1}\right)=$ concentration of estrone;
$\left(E_{2}\right)=$ concentration of estadriol;
$\left(C_{1}\right)=$ concentration of estrone conjugates;
$\left(C_{2}\right)=$ concentration of estadiol conjugates;
(A) = concentration of total conjugates at steady-state when estrone is administered intravenously;
(B) = concentration of total conjugates at steaủy-state when estradiol is administered intravenously.

The subscripts $S$ and $D$ indicate the source of the species from the zero-order infusion of estrone and estradiol, respectively.

The effective bioconversion rate constants in $\mathrm{cm}^{3} / \mathrm{h}$ are defined as follows:

$k_{1}=$ rate constant of estrone to estradiol;

$\mathrm{k}_{2}=$ rate constant of estradiol to estrone; 
$\mathbf{k}_{\mathbf{3}}=$ rate constant of estrone to estrone conjugates;

$\mathrm{k}_{\mathbf{4}}=$ rate constant of estradiol to estradiol conjugates.

These constants are the product of the volume of distribution and their corresponding first-order bioconversion rate constants.

The other constants are:

$\mathbf{R} \quad=$ intravenous infusion rate of estrone or estradiol $(\mu \mathrm{g} / \mathrm{h})$;

$k_{e 1}$ and $k_{e 2}=$ effective elimination rate constant of the conjugates of estrone and estradiol, respectively, in $\mathrm{cm}^{3} / \mathrm{h}$.

As will be seen, the parameters of $R,\left(E_{1}\right)_{S},\left(E_{2}\right)_{S},\left(E_{1}\right)_{D},\left(E_{2}\right)_{D},(A)$ and $(B)$ are known explicitly from the experimental data. Using these known quantities anc solving the system of 10 equations (Eqns. 1-10) the following unknowns can be determired:

$$
k_{1}=\frac{R}{\frac{\left(E_{2}\right)_{D}\left(E_{1}\right)_{S}}{\left(E_{2}\right)_{S}}-\left(E_{1}\right)_{D}}
$$

$k_{2}=\frac{R}{\frac{\left(E_{1}\right)_{S}\left(E_{2}\right)_{D}}{\left(E_{1}\right)_{D}}-\left(E_{2}\right)_{S}}$

$k_{3}=\frac{R-k_{1}\left(E_{1}\right)_{S}+k_{2}\left(E_{2}\right)_{S}}{\left(E_{1}\right)_{S}}=k_{2} \frac{\left(E_{2}\right)_{D}}{\left(E_{1}\right)_{D}}-k_{1}$

$k_{4}=\frac{R+k_{1}\left(E_{1}\right)_{D}-k_{2}\left(E_{2}\right)_{D}}{\left(E_{2}\right)_{D}}=k_{1} \frac{\left(E_{1}\right)_{S}}{\left(E_{2}\right)_{S}}-k_{2}$

$\left(C_{2}\right)_{D}=\frac{(A)-\frac{\left(E_{1}\right)_{S}}{\left(E_{1}\right)_{D}} \cdot(B)}{\frac{\left(E_{2}\right)_{S}}{\left(E_{2}\right)_{D}}-\frac{\left(E_{1}\right)_{S}}{\left(E_{1}\right)_{D}}}$

$\left(C_{1}\right)_{D}=(B)-\left(C_{2}\right)_{D}$

$\left(C_{1}\right)_{S}=\frac{\left(E_{1}\right)_{S}\left(C_{1}\right)_{D}}{\left(E_{1}\right)_{D}}$

$\left(C_{2}\right)_{S}=(A)-\left(C_{1}\right)_{S}$

$k_{e l}=k_{3} \frac{\left(E_{1}\right)_{S}}{\left(C_{1}\right)_{S}}=k_{3} \frac{\left(E_{1}\right)_{D}}{\left(C_{1}\right)_{D}}$

$k_{e 2}=k_{4} \frac{\left(E_{2}\right)_{S}}{\left(C_{2}\right)_{S}}=k_{4} \frac{\left(E_{2}\right)_{D}}{\left(C_{2}\right)_{D}}$ 


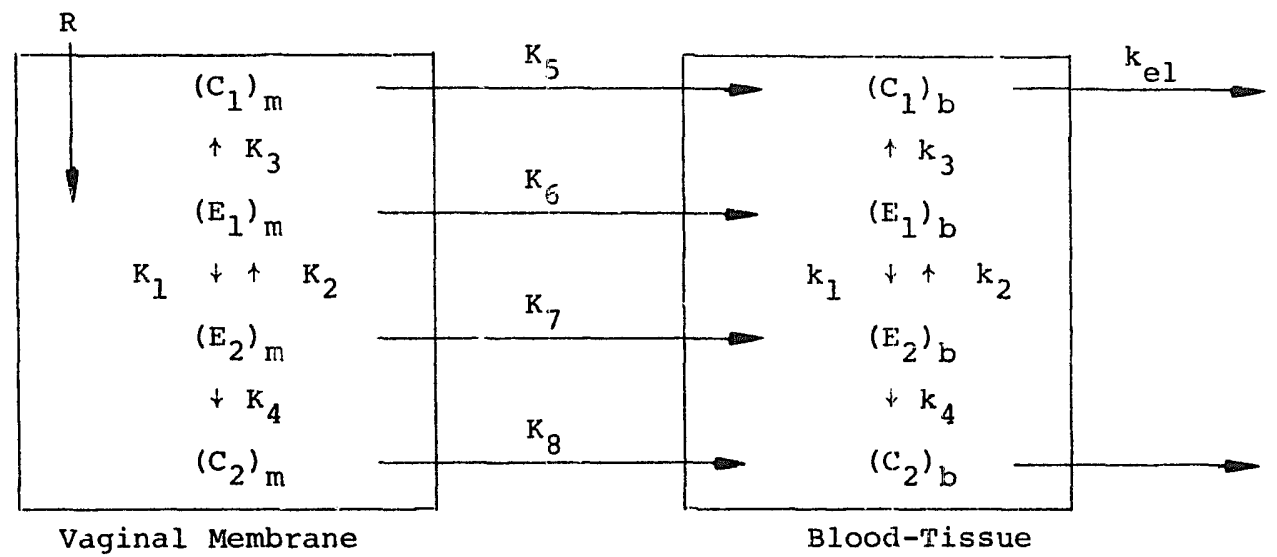

Scheme 2. Zero-order vaginal infusion of estrone (or estradiol) and pharmacokinetic processes in the vaginal membrane and blood-tissue compartments.

Case II: Zero-order vaginal infusion of estrone (or estradiol) and their steady-state plasma levels

The pharmacokinetic model for the vaginal membrane and blood compartments for this case is shown in Scheme 2. First-order kinetic processes are assumed and the steadystate pharmacokinetic expressions are described below.

(a) Steady-state pharmacokinetic expressions in the membrane following zero-order vaginal infusion of estrone ${ }^{1}$

$\frac{\mathrm{d}\left(\mathrm{E}_{1}\right)_{\mathrm{m}}}{\mathrm{dt}}=\mathrm{R}-\mathrm{K}_{\mathrm{i}}\left(\mathrm{E}_{1}\right)_{\mathrm{m}}+\mathrm{K}_{2}\left(\mathrm{E}_{2}\right)_{m}-\mathrm{K}_{3}\left(\mathrm{E}_{1}\right)_{m}-\mathrm{K}_{6}\left(\mathrm{E}_{1}\right)_{\mathrm{m}}=0$

$\frac{d\left(E_{2}\right)_{m}}{d t}=K_{1}\left(E_{1}\right)_{m}-K_{2}\left(E_{2}\right)_{m}-K_{4}\left(E_{2}\right)_{m}-K_{7}\left(E_{2}\right)_{m}=0$

$\frac{\mathrm{d}\left(\mathrm{C}_{1}\right)_{\mathrm{m}}}{\mathrm{dt}}=\mathrm{K}_{3}\left(\mathrm{E}_{1}\right)_{\mathrm{m}}-\mathrm{K}_{5}\left(\mathrm{C}_{1}\right)_{\mathrm{m}}=0$

$\frac{\mathrm{d}\left(\mathrm{C}_{2}\right)_{\mathrm{m}}}{\mathrm{dt}}=\mathrm{K}_{4}\left(\mathrm{E}_{2}\right)_{\mathrm{m}}-\mathrm{K}_{8}\left(\mathrm{C}_{2}\right)_{\mathrm{m}}=0$

${ }^{1}$ In the case of zero-order vaginal infusion of estradiol, Eqn. 21 becomes:

$\frac{\mathrm{d}\left(\mathrm{E}_{1}\right)_{\mathrm{m}}}{\mathrm{dt}}=-\mathrm{K}_{1}\left(\mathrm{E}_{1}\right)_{\mathrm{m}}+\mathrm{K}_{2}\left(\mathrm{E}_{2}\right)_{\mathrm{m}}-\mathrm{K}_{3}\left(\mathrm{E}_{1}\right)_{\mathrm{m}}-\mathrm{K}_{6}\left(\mathrm{E}_{1}\right)_{\mathrm{m}}=0$

and Eqn. 22 becomes:

$\frac{\mathrm{d}\left(\mathrm{E}_{2}\right)_{\mathrm{m}}}{\mathrm{dt}}=\mathrm{R}+\mathrm{K}_{1}\left(\mathrm{E}_{1}\right)_{\mathrm{m}}-\mathrm{K}_{2}\left(\mathrm{E}_{2}\right)_{\mathrm{m}}-\mathrm{K}_{4}\left(\mathrm{E}_{2}\right)_{\mathrm{m}}-\mathrm{K}_{7}\left(\mathrm{E}_{2}\right)_{\mathrm{m}}=0$

Equations 23-29 remain the same. 
(b) Steady-state pharmacokinetic expressions in the blood following zero-order vaginal infusion of estrone

$$
\begin{aligned}
& \frac{d\left(E_{1}\right)_{b}}{d t}=K_{6}\left(E_{1}\right)_{m}-k_{1}\left(E_{1}\right)_{b}+k_{2}\left(E_{2}\right)_{b}-k_{3}\left(E_{1}\right)_{b}=0 \\
& \frac{d\left(E_{2}\right)_{b}}{d t}=K_{7}\left(E_{2}\right)_{m}+k_{1}\left(E_{1}\right)_{b}-k_{2}\left(E_{2}\right)_{b}-k_{4}\left(E_{2}\right)_{b}=0 \\
& \frac{d\left(C_{1}\right)_{b}}{d t}=k_{3}\left(E_{1}\right)_{b}-k_{e 1}\left(C_{1}\right)_{b}+K_{5}\left(C_{1}\right)_{m}=0 \\
& \frac{d\left(C_{2}\right)_{b}}{d t}=k_{4}\left(E_{2}\right)_{b}-k_{e 2}\left(C_{2}\right)_{b}+K_{8}\left(C_{2}\right)_{m}=0 \\
& (G)=\left(C_{1}\right)_{b}+\left(C_{2}\right)_{b}
\end{aligned}
$$

The concentrations of various species in the vaginal membrane (designated by subscript $\mathrm{m}$ ) and blord (subscript b) in $\mu \mathrm{g} / \mathrm{ml}$ following the zero order vaginal infusion of estrone are:

$\left(E_{1}\right)_{m}$ and $\left(E_{1}\right)_{b}=$ estrone concentrations;

$\left(E_{2}\right)_{m}$ and $\left(E_{2}\right)_{b}=$ estradiol concentrations;

$\left(C_{1}\right)_{m}$ and $\left(C_{1}\right)_{b}=$ concentrations of estrone conjugates;

$\left(C_{2}\right)_{m}$ and $\left(C_{2}\right)_{b}=$ concentrations of estradiol conjugates;

(G) = total conjugate concentration of estrone and estradiol.

The effective bioconversion rate constants in the membrane in $\mathrm{cm}^{3} / \mathrm{h}$ are given by:

$\mathrm{K}_{1}=$ rate constant of estrone to estradiol;

$\mathrm{K}_{2}=$ rate constant of estradiol to estrone;

$\mathrm{K}_{\mathbf{3}}=$ rate constant of estrone to estrone conjugates;

$\mathrm{K}_{\mathbf{4}}=$ rate constant of estradiol to estradiol conjugates;

whereas, the rate constants for the transfer of the various species from the membrane to blood in $\mathrm{cm}^{3} / \mathrm{s}$ are:

$\mathrm{K}_{6}$ and $\mathrm{K}_{7}=$ transfer rate constants for estrone and estradiol, respectively;

$\mathrm{K}_{\mathbf{5}}$ and $\mathrm{K}_{\mathbf{8}}=$ transfer rate constants for the conjugates of estr $r$ ne and estradiol, and respectively;

$\mathbf{R}=$ zero-order vaginal infusion rate of estrone $(\mu \mathrm{g} / \mathrm{h})$ which is also equal to the zero-order intravenous infusion rate

While the $R,\left(E_{1}\right)_{b},\left(E_{2}\right)_{b}$ and $(G)$ quantities are readily determined from the experimental data, the metabolism constants, $\mathrm{k}_{1} \ldots \mathrm{k}_{4}$, on the blood side and the elimination constants, $\mathrm{k}_{\mathrm{e} i \mathrm{i}}$ and $\mathrm{k}_{\mathrm{e} 2}$, are determined by the intravenous infusion pharmacokinetic studies pieviously described. Subsequently, various unknown parameters can be calcu- 
lated:

$\left(C_{2}\right)_{\mathrm{b}}=\frac{\mathrm{k}_{\mathrm{e} 1}(\mathrm{G})-\mathrm{R}}{\mathrm{k}_{\mathrm{e}_{1}}-\mathrm{k}_{\mathrm{e} 2}}$

$\left(\mathrm{C}_{1}\right)_{\mathrm{b}}=(\mathrm{G})-\left(\mathrm{C}_{2}\right)_{\mathrm{b}}$

$K_{6}\left(E_{1}\right)_{m}=k_{1}\left(E_{1}\right)_{b}-k_{2}\left(E_{2}\right)_{b}+k_{3}\left(E_{1}\right)_{b}$

$\mathrm{K}_{7}\left(\mathrm{E}_{2}\right)_{m}=\mathrm{k}_{2}\left(\mathrm{E}_{2}\right)_{b}-\mathrm{k}_{1}\left(\mathrm{E}_{1}\right)_{\mathrm{b}}+\mathrm{k}_{4}\left(\mathrm{E}_{2}\right)_{\mathrm{b}}$

$\mathrm{K}_{4}\left(\mathrm{E}_{2}\right)_{\mathrm{m}}=\mathrm{K}_{5}\left(\mathrm{C}_{1}\right)_{\mathrm{m}}=\mathrm{k}_{\mathrm{e} 1}\left(\mathrm{C}_{1}\right)_{\mathrm{b}}-\mathrm{k}_{3}\left(\mathrm{E}_{1}\right)_{\mathrm{b}}$

$\mathrm{K}_{3}\left(\mathrm{E}_{1}\right)_{\mathrm{m}}=\mathrm{K}_{8}\left(\mathrm{C}_{2}\right)_{\mathrm{m}}=\mathrm{k}_{\mathrm{e} 2}\left(\mathrm{C}_{2}\right)_{\mathrm{b}}-\mathrm{k}_{4}\left(\mathrm{E}_{2}\right)_{\mathrm{b}}$

$K_{1}\left(E_{1}\right)_{m}-K_{2}\left(E_{2}\right)_{m}=K_{4}\left(E_{2}\right)_{m}+K_{7}\left(E_{2}\right)_{m}$

The membrane bioconversion constants, $\mathrm{K}_{1} \ldots \mathrm{K}_{4}$, and the transfer rate constants, $\mathrm{K}_{5} \ldots \mathrm{K}_{8}$, are difficult to obtain unless the membrane concentrations of the various species are determined. However, as will be seen, one can yet determine the extent of membrane metabolism of the vaginaliy infused estrone or estradiol.

\section{EXPERIMENT AL}

\section{Animal care}

A mature female Macaques rhesus monkey ( 5 years old and $7.4 \mathrm{~kg}$ in weight) was employed. She was maintained under routine animal health care regimen by the animal care personnel in an air-conditioned building and given free access to food and water. The menstrual periods were normal, about a 30 -day cycle. The overall procedures and repetition of the experimertal studies did not have any observed effects on the appetite, weight and physical appearance. Periodic vaginal examinations by a veterinarian revealed no signs of infection and tissue damage throughout the study. All experiments were performed within 5-20 days post-menstruation. The monkey rested for at least 10 days between experiments.

The monkey was anesthetized by administering approximately $20 \mathrm{mg} / \mathrm{kg}$ of ketamine hydrochloride intramuscularly. The level of anesthetization was maintained by administering addition?l doses of ketamine every half-hour for the duration of the experiment.

\section{Materials}

$\left[6,7-{ }^{3} \mathrm{H}\right]$ Estrone $(51.8 \mathrm{Ci} / \mathrm{mmol}), \quad\left[4-{ }^{14} \mathrm{C}\right]$ estrone $(59 \mathrm{mCi} / \mathrm{mmol}), \quad\left[6,7 \cdot{ }^{3} \mathrm{H}\right] 17 \beta-$ estradiol $(60 \mathrm{Ci} / \mathrm{mmol})$ and $\left[4{ }^{14} \mathrm{C}\right] 17 \beta$-estradiol $(55.7 \mathrm{mCi} / \mathrm{mmol})$ were purchased ${ }^{2}$. They were further purified by TLC using silica gel, $250 \mu \mathrm{m}$ thick, precoated plates ${ }^{3}$ and $10 \%$ ethanol in benzene solvent system (Touciestone et al., 1968). The $R_{f}$ values of radiolabeled estradiol and estrone were 0.58 and 0.73 , respectively, and were identical

\footnotetext{
2 New England Nuclear, Boston, Mass. 02118 , U.S.A.

${ }^{3}$ Analtech, Inc., Newark, Dela., U.S.A.
} 
with authentic samples. After scraping the appropriate silica gel sections, the estrogens were extracted with benzene. The benzene was evaporated with the aid of a nitrogen stream before using the purified estrogens.

Non-radiolabeled estrone ${ }^{4}$, and Aquasol ${ }^{2}$, spectrograde benzene and propylene glycol USP were employed. Buffer $\mathrm{pH} 6.0$ solution was prepared by dissolving $13.8 \mathrm{~g}$ of monobasic sodium phosphate in $10 \mathrm{ml}$ of $1.0 \mathrm{~N}$ sodium hydroxide and then distilled water was added to make a final volume of one liter. The solution was made isotonic by the addition of sodium chloride.

\section{Vagina perfusion method}

The details of the closed vaginal perfusion system have been described before (Owada et al., 1977). After insertion of the rib cage cell in the vagina of the anesthesized monkey, the vaginal cavity was perfused with normal saline irrigation solution for about $15 \mathrm{~min}$ at a flow rate of $20 \mathrm{ml} / \mathrm{min}$ to remove exfoliated cells and secretions. After the perfusate was discarded, $10 \mathrm{ml}$ isotonic phosphate buffer $\mathrm{pH} 6.0$ solution was perfused for $5 \mathrm{~min}$ to condition the vagina, and then $5 \mathrm{ml}$ of the radiolabeled drug solution containing phosphate buffer was introduced into the perfusion circuit. The closed perfusion system consists of approximately $15 \mathrm{ml}$ total volume in the reservoir, tubing and rib-cage cell. To allow the drug to distribute throughout the system, the 'zero-time' sample was taken after a 10-min mixing period. Thereafter, samples were withdrawn at 10, 20, 40 and $50 \mathrm{~min}$. Each sample was diluted in $10 \mathrm{ml}$ of scintillation fluid and counted with a Beckman LS-20 scintillation spectrorneter. Repetitive, consecutive 1-h experiments in the same monkey were carried out is desired by replacing the drug reservoir flask with another flask containing $15 \mathrm{ml}$ fresh drug perfusion solution. To follow the disappearance kinetics, dilute solutions of radiolabeled estradiol and estrone, a pproximately $7.8 \times 10^{-2}$ $\mu \mathrm{g} / \mathrm{ml}$, were utilized. In one experiment, a solution of estrone in phosphate buffer bordering on saturation was used; it was prepared from the conbination of radiolabeled and cold estrone.

Zero-order vaginal infusion studies were carried out in the following manner. In accordance with the experimental design, efforts were made to assure that the zero-order vaginal infusion rate of estrone and estradiol was identical to the zero-order intravenous infusion rate of $0.21 \mu \mathrm{g} / \mathrm{h}$. As will be seen from the disappearance kinetic studies of estrone and estradiol in the vagina, estrone and estradiol are absorbed at the rate of about 19 and $12 \%$ per hour, respectively. Thus, vaginal perfusion solutions were prepared to contain about $0.364 \mu \mathrm{g} / \mathrm{ml}$ of radiolabeled estrone or $0.578 \mu \mathrm{g} / \mathrm{ml}$ of estradiol in $\mathrm{pH} 6.0$ phosphate buffer. After $1 \mathrm{~h}$ of vaginal infusion of the estrogen, the reservoir flask was replaced by another flask of $15 \mathrm{ml}$ fresh drug solution. The procedure was repeated each hour for 8 consecutive hours. Meanwhile, blood samples were withdrawn at 90,150, 210, 270,330 and 390 (or 420) $\mathrm{min}$ from the time when the perfusate was first introduced in the vagina. The procedures for withdrawing blood and quantitative analysis of estrone, estradiol and their conjugates in the blood samples are described in the sections to follow.

\footnotetext{
${ }^{4}$ Analats, Inc., North Haven, Conn. 46473, U.S.A.
} 


\section{Zero-order intravenous infusion method}

A stock solution vehicle containing $10 \%$ ethanol and $20 \%$ propylene glycol in normal saline was sterilized by microfiltration ${ }^{5}$. Twenty $\mathrm{ml}$ was used to solubilize the purified, radiolabeled estrogens to give a concentration of estrone and/or estradiol or approximately $0.07 \mu \mathrm{g}^{\prime} \mathrm{mi}$ each. The solution was transferred to a $30 \mathrm{ml}$ glass syringe connected to an intravenous administration set ${ }^{6}$ and a constant infusion pump ${ }^{7}$. The drug was then infused into the saphenous vein at a pump rate of $3 \mathrm{ml} / \mathrm{h}$ so that the final infusion rate of either estrone or estradiol was $0.21 \mu \mathrm{g} / \mathrm{h}$. With the aid of a heparinized syringe and an indwelling Teflon tubing ( $2 \mathrm{~mm}$ o.d., $1.5 \mathrm{~mm}$ i.d. and $30 \mathrm{~cm}$ length) ${ }^{8}$ connected to a 17-gauge needle stem in the vein of the opposite leg, $5 \mathrm{ml}$ blood samples were withdrawn periodically and quantitatively assayed.

\section{Assay of blood plasma samples}

The $5 \mathrm{ml}$ blood samples were immediately centrifuged at $800 \mathrm{G}$ for $10 \mathrm{~min}$ upon withdrawal. One-tenth $\mathrm{ml}$ of the plasma fraction was added directly to $10 \mathrm{ml}$ scintillation fluid and counted to get the total radioactivity. Next, $0.5 \mathrm{ml}$ of the plasma was diluted to $1 \mathrm{ml}$ with phosphate buffer and then extracted successively with one $1.5 \mathrm{ml}$ and four $1.0 \mathrm{ml}$ portions of benzene. The benzene extracts containing the expected radiolabeled estrone and estradiol were combined, concentrated by evaporation with a stream of nitrogen and spotted on TLC silica gel plates. After development in $10 \%$ ethanol in benzene solvent, the plates were air-dried and divided into $0.5 \mathrm{~cm}$ sections. Each section was quantitatively scraped into $10 \mathrm{ml}$ scintillation fluid and counted to establish the estrone/estradiol ratio.

From the benzene extracted plasma, $0.1 \mathrm{ml}$ was transferred to scintillation vials containing $10 \mathrm{ml}$ fluid to determine the concentration of the total hydrophilic conjugates of estrone and estradiol, presumably the sulfate and glucuronide conjugates.

\section{Metabolism in vaginal secretions and back-diffusion of metabolites}

The occurrence of metabolism of estrone and estradiol in vaginal secretions was assessed in vitro with perfusates containing vaginal secretions. Fifteen $\mathrm{ml}$ of isotonic phosphate buffer at pH 6.0 was perfused in the vagina for one hour and then collected. Approxirnately $7.8 \cdot 10^{-2} \mu \mathrm{g}$ of $\left[{ }^{3} \mathrm{H}\right]$ estrone or $\left[{ }^{3} \mathrm{H}\right]$ estradiol and added to $1 \mathrm{ml}$ of the perfusate, incubated for $1 \mathrm{~h}$ at $37^{\circ} \mathrm{C}$, and assayed by TLC and liquid scintillation counting.

The extent of back-diffusion of metabolites from the vaginal membrane during the course of the absorption experiments was determined by withdrawing $1 \mathrm{ml}$ of the perfusion solution and carrying out quantitative TLC procedures. The radiolabeled metabolites of estrone and estradiol were assayed by liquid scintillation.

\footnotetext{
${ }^{5}$ Millex Filter System, Millipore Corp., Bedford, Mass. 01730, U.S.A.

${ }^{6}$ Butterfly short-26G, Abbott Lab., N. Chicago, Ill. 60064, U.S.A.

${ }^{7}$ Harvard Apparatus Co., Inc., Dover, Mass., U.S.A.

8 Anspec Company, Ann Arbor, Mich. 48107, U.S.A.
} 


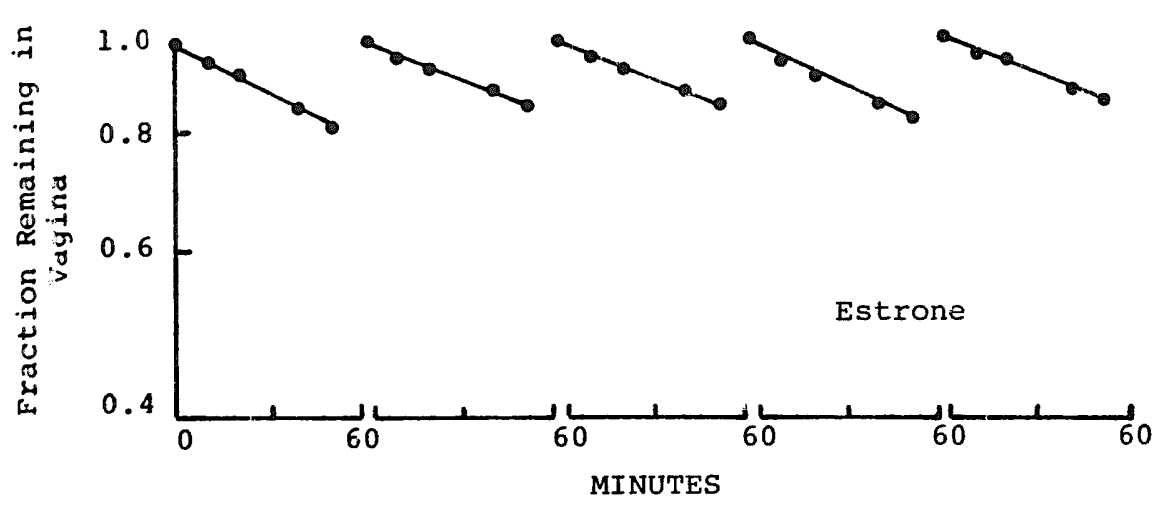

Fig. 1. Disappearance kinetics of dilute aqueous $\left[{ }^{3} \mathrm{H}\right.$ ]estrone solution $\left(7.8 \times 10^{-2} \mu \mathrm{g} / \mathrm{ml}\right)$ at $\mathrm{pH} 6.0$ and $37^{\circ} \mathrm{C}$ in the vagina. All hourly experiments were repeated and carried out in the same monkey within a 6 h continuous period.

\section{RESULTS AND DISCUSSION}

\section{Steady-state vaginal absorption of estrone and estradiol}

Figs. 1 and 2 show the semilogarithmic change in the fraction of dilute estrone and estradiol concentrations, respectively, remaining in the vaginal lumen with time. The disappearance follows a first-order pattern. Constant absorption rates are obtained over a 6-8 $\mathrm{h}$ period by performing consecutive, repetitive experiments of $1 \mathrm{~h}$ duration, each with fresh estrogen solutions. The absorption rates are 19.2\% ( \pm 2.2 S.D.) per hour for estrone and $12.1 \%( \pm 3.9$ S.D.) per hour for estradiol.

The results of five successive absorption experiments in a $t-h$ period in the same monkey with saturated aqueous solutions of estrone at $\mathrm{pH} 6.0$ ale shown in Fig. 3. The absorption rate is $19.4 \%$ ( \pm 2.4 S.D.) per hour when saturated aqueous solutions are used and is not significantly different from $19.2 \%$ ( \pm 2.2 S.D.) per hour for the dilute solution situation. This is a good indication that the vaginal transport of estrone is independent of

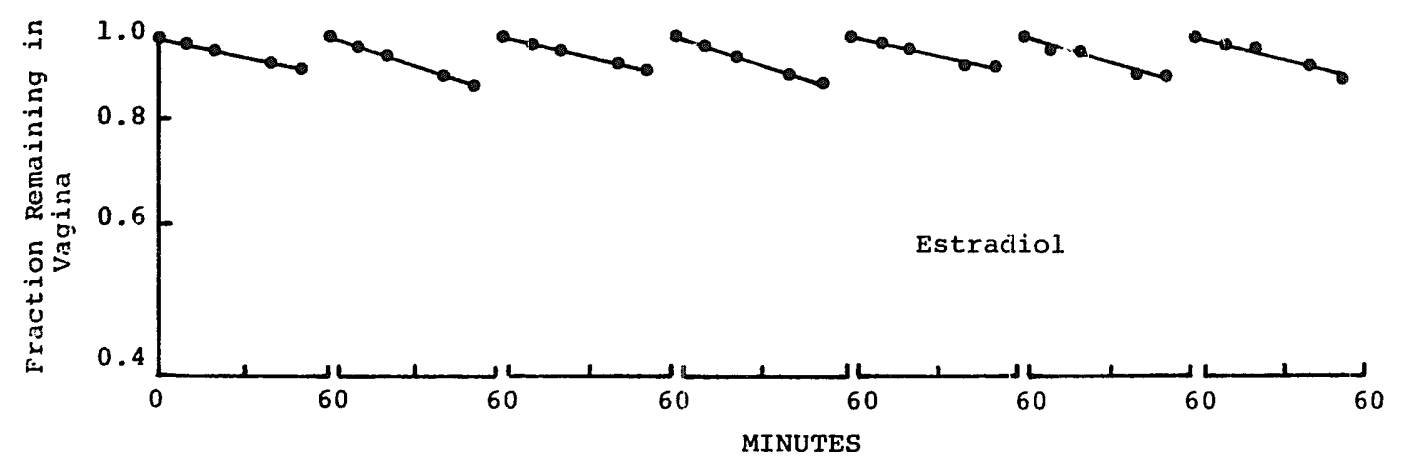

Fig. 2. Disappearance kinetics of dilute aqueous $\left[{ }^{3} \mathrm{H}\right]$ estradiol solutions $\left(7.8 \times 10^{-2} \mu \mathrm{g} / \mathrm{ml}\right)$ at $\mathrm{pH} 6.0$ and $37^{\circ} \mathrm{C}$ in the vagina. All hourly experiments were repeated and carried out in the same monkey within a continuous $8 \mathrm{~h}$ period. 


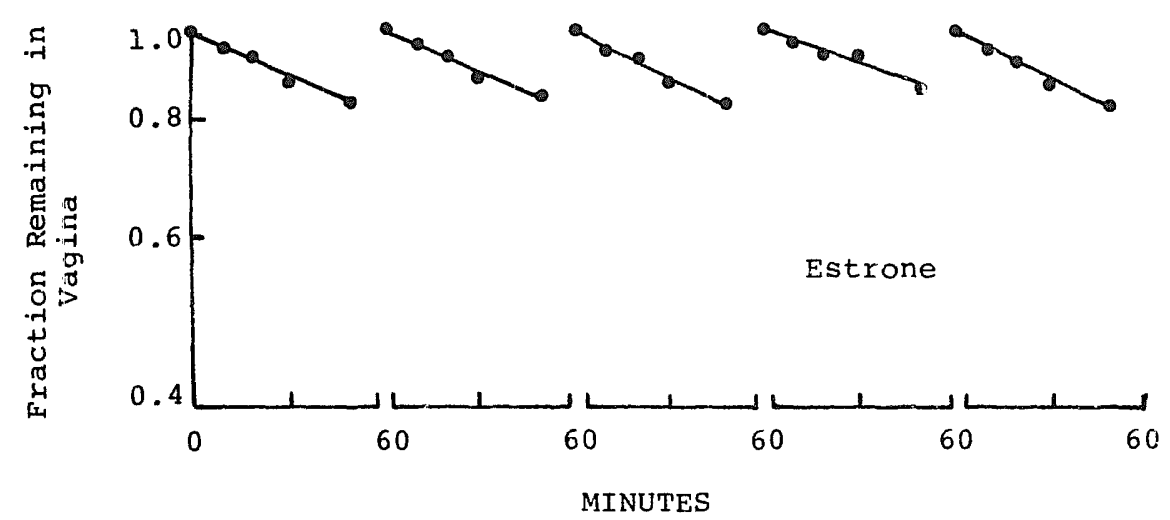

Fig. 3. Disappearance kinetiss of initially saturated aqueous estrone solutions $(\sim 30 \mu \mathrm{g} / \mathrm{ml})$ at $\mathrm{pH} 6.0$ and $37^{\circ} \mathrm{C}$. All houriy experiments were repeated and carried out in the same monkey within a continuous 6-h period.

concentration up to its aqueous solubility and that membrane metabolism, which would play a facilitative role in drug uptake, is also first-order up to the point of saturation. Although no similar absorption studies were carried out with saturated solutions of estradiol in water, the assumption that the metabolism rate in the vaginal membrane is also in the non-saturable kinetic region has been applicd to this substrate as well, based on the estrone experience.

The apparent permeability coefficients of estrone and estradiol are "ound in Table 1. These were determined from the following expression:

$P_{\mathrm{app}}=\frac{K_{\mathrm{u}}}{\mathrm{A} / \mathrm{V}}$

where

$\mathrm{P}_{\mathrm{app}}=$ apparent permeability coefficient;

$\mathrm{K}_{\mathrm{u}}=$ first-order disappearance rate constant;

$\mathrm{A} / \mathrm{V}=$ surface area to volume ratio.

The search for metabolic products in the vaginal perfusion solution after a 1 -h period by quantitative TLC procedures showed insignificant traces of estrons and about $2 \%$ total conjugates when estradiol was administered and about $5 \%$ estradiol and 3\% total conjugates during estrone perfusion. The in vitro incubation of estrone and estradiol in vaginal secretions in $\mathrm{pH} 6.0$ phosphate buffer indicated the presence of conjugates to the extent of $0.5 \%$ in $1 \mathrm{~h}$. Also, no interconversion of estrone to estradiol and vice versa was detected.

\section{Zero-order intravenous infusion studies of estrone and estradiol}

The plasma concentration level-time relationships for the total conjugates, estrone and estradiol, obtained by the zero-order intravenous infusion of $50: 50$ mixture of $\left[{ }^{14} \mathrm{C}\right]$ estrone and $\left[{ }^{3} \mathrm{H}\right]$ estradiol solution at the rate of $0.05 \mathrm{ml} / \mathrm{min}$, are shown in Fig. 4 . 


\section{TABLE 1}

RATE CONSTANTS AND APPARENT PERMEABILITY COEFFICIENTS OF ESTRONE AND ESTRADIOL FROM IN SITU DISAPPEARANCE KINETICS IN THE VAGINA

$A=8 \mathrm{~cm}^{2}$ and $V=16.74 \mathrm{~cm}^{3}$.

\begin{tabular}{|c|c|c|}
\hline Parameters & Estrone $^{\mathbf{a}}$ & Estradiol $^{\mathbf{a}}$ \\
\hline $\begin{array}{l}K_{\mathrm{u}}, \mathrm{s}^{-1} \\
\mathrm{~A} / \mathrm{V}, \mathrm{cm}^{-1} \\
P_{\mathrm{app}}, \mathrm{cm} / \mathrm{s}\end{array}$ & $\begin{array}{l}5.89( \pm 0.68) \times 10^{-5} \\
0.478 \\
12.4( \pm 1.43) \times 10^{-5}\end{array}$ & $\begin{array}{l}3.94( \pm 1.05) \times 10^{-5} \\
0.478 \\
8.24( \pm 2.2) \times 10^{-5}\end{array}$ \\
\hline
\end{tabular}

a Calculations based on 10 experiments for estrone and 7 experiments for estradiol.

Steady-state estrone and estradiol plasma levels are clearly established in 3-4 h whereas the plateau of total conjugates of estradiol and estrone develops within $6 \mathrm{~h}$. The plateau concentrations, particularly those for estrone and estradiol, will provide the basis for the determination of the first-order metabolism constants.

\section{Zero-order vaginal and intravenous infusion of estrone and estradiol}

The res:lts of the simultaneous zero-order vaginal infusion of $\left[{ }^{3} \mathrm{H}\right]$ estradiol and intravenous infusion of $\left[{ }^{14} \mathrm{C}\right]$ estradiol at the rate of $0.21 \mu \mathrm{g} / \mathrm{h}$ are given in Fig. 5 and, likewise, for $\left[{ }^{3} \mathrm{H}\right]$ estrone vaginally and $\left[{ }^{14} \mathrm{C}\right]$ estrone intravenously in Fig. 6 . When the results of the intravenous infusion experiments of estrone and estradiol in Fig. 5A and 6A are considered, it is discovered that the concentiation-time profiles are essentially the same as found when these estrogens were co-admiristered (Fig. 4). The pooling of these results is, therefore, justified. It is apparent that the plasma levels of both estrone and estradiol are higher when they are administered int:avenously than when administered by the vaginal route.

\section{Analysis of daia and bioavailabiitity assessment}

As can be seen by the differences in species profiles in Figs. 4-6, radiolabeled estrone is converted to estradiol and polar conjugates by the vaginal membrane and/or other tissues on the blood side. Likewise, radiolabeled estradiol is metabolized to estrone and conjugates. These conjugates were not chemically characterized but are presumably the glucuronide and sulfate conjugates of estrone and estradiol. The average plateau plasma concentrations of estrone and estradiol after the zero-order infusion of the estrogens are shown in Table 2. In the administration of estrone, the plasma lev 1 of estrone was $1.7 \times 10^{-5} \mu \mathrm{g} / \mathrm{ml}$ by intravenous infusion and $0.82 \times 10^{-5} \mu \mathrm{g} / \mathrm{ml}$ by vaginal infusion. However, the levels of the estridiol metabolite of estrone were nearly the same by both routes of administration of estrone. When estradiol was given, the estradiol plasma level was $3.22 \times 10^{-5} \mu \mathrm{g} / \mathrm{ml}$ by intravenous infusion and $1.23 \times 10^{-5} \mu \mathrm{g} / \mathrm{ml}$ by the vaginal route. Thus, membrane metabolism of estrone has the effect of reducing the estrone blood level by about $55 \%$ of that expected in the absence of membrane metabolism. 


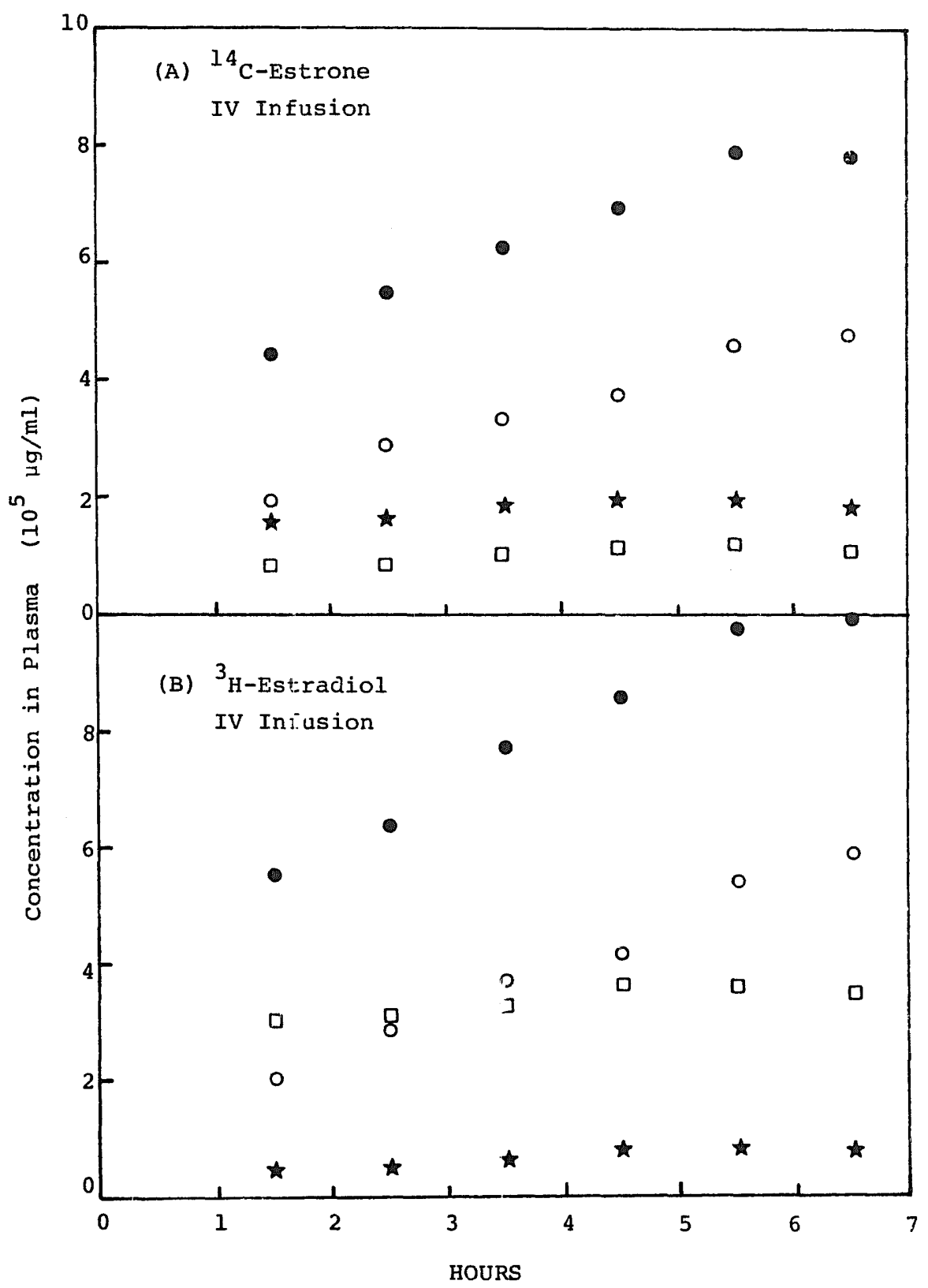

Fig. 4. Plasma cencentrations of estrone, estradiol and total conjugates with time following the zeroorder intravenous infusion of a $50: 50$ mixture of $\left[{ }^{14} \mathrm{C}\right]$ estrone and $\left[{ }^{3} \mathrm{H}\right]$ estradiol at $0.21 \mu \mathrm{g} / \mathrm{h}$ for each estrogen. $\bullet$, Total activity; $\circ$, conjugates; *, estrone; $\square$, estradiol.

Almost the same conclusion is reached in the case of estradiol, the reduction being about 61;

The approach used to factor the extent of metabolism of vaginally administered estrone and estradiol remains to be considered. Using the plateau values obtained from the intravenous administration of estrone and estradiol in Table 2 and also Eqns. 11-14, 


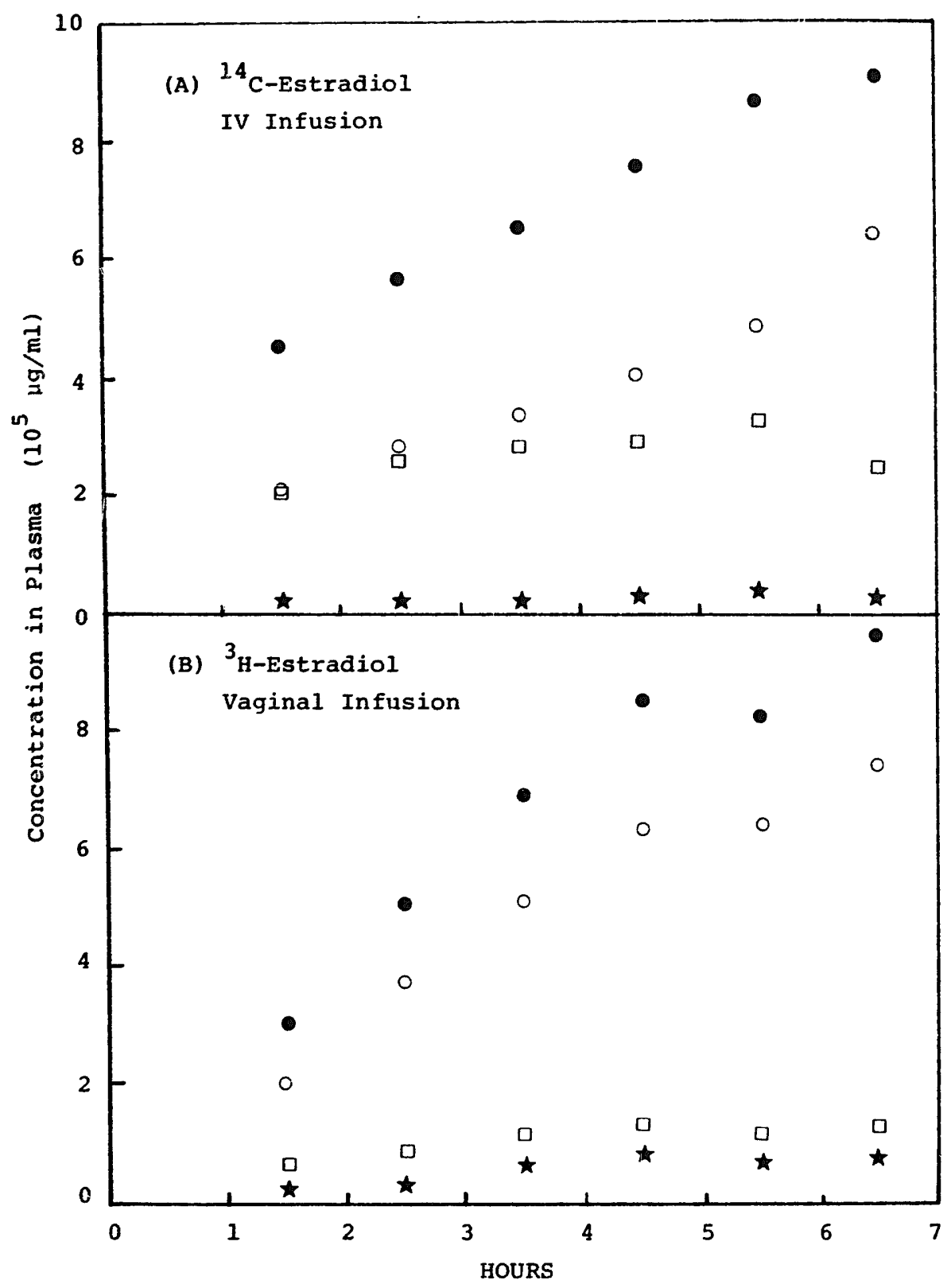

Fig. 5. Plasma concentrations of estradiol, estrone and total conjugates with time following the simultaneous zero-order infusion of $\left[{ }^{14} \mathrm{C}\right]$ estradiol intravenously and $\left[{ }^{3} \mathrm{H}\right]$ estradiol vaginally. All infusion rates were $0.21 \mu \mathrm{g} / \mathrm{h}$. $\bullet$, Total activity; $\circ$, conjugates; $\star$, estrone; $\square$, estradiol.

the following apparent first-order rate constants of metabolism on the blood side are:

estrone to estradiol:

$$
\mathrm{k}_{1}=5.07 \times 10^{3} \mathrm{~cm}^{3} / \mathrm{h}
$$

estradiol to estrone:

$\mathrm{k}_{2}=2.64 \times 10^{3} \mathrm{~cm}^{3} / \mathrm{h}$;

estrone to estrone conjugates: $\quad k_{3}=9.09 \times 10^{3} \mathrm{~cm}^{3} / \mathrm{h}$; 
estradiol to estradiol conjugates: $\mathrm{k}_{4}=4.83 \times 10^{3} \mathrm{~cm}^{3} / \mathrm{h}$.

It is noted that the calculation of the above constants, $k_{1} \ldots k_{4}$, requires only the knowledge of the infusion rates and the plateau plasma concentrations of estrone and estradiol.

Consequently, the recycling of the above rate constants and the plasma leve's obtained from the vaginal infusion of estrone and estradioi, as summarized in Table 2, into Eans.

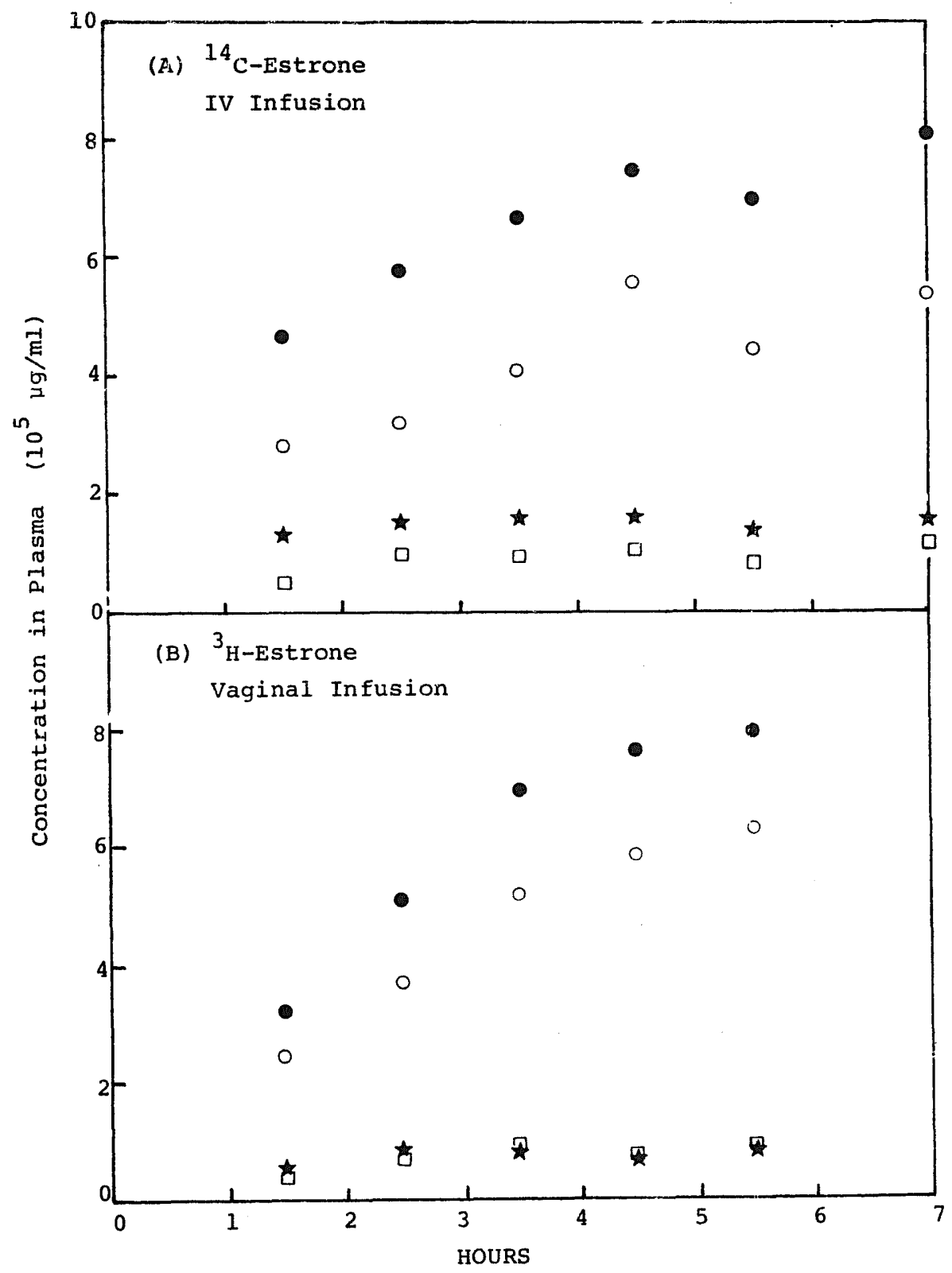

Fig. 6. Plasma concentrations of estradiol, estrone and total conjugates with time following the simultaneous zero-order infusion of $\left[{ }^{14} \mathrm{C}\right]$ estrone intravenously and $\left[{ }^{3} \mathrm{H}\right]$ estrone vaginally. All infusion rates were $0.21 \mu \mathrm{g} / \mathrm{h} . \bullet$, Tutal activity; $\circ$, conjugates; $\star$, estrone; $\square$, estradiol. 
TABLE 2

AVERAGE PLATEAU PLASMA CONCENTRATIONS OF ESTROINE AND ESTR IDIOL AFTER ZERO-ORDER VAGINAL AND INTRAVENOUS INFUSION OF ESTFONE AND E ${ }^{\circ}$ 'TRADIOL

\begin{tabular}{|c|c|c|c|c|}
\hline \multirow[t]{2}{*}{$\begin{array}{l}\text { Estrogen } \\
\text { infused a }^{a}\end{array}$} & \multirow[t]{2}{*}{$\begin{array}{l}\text { Route of } \\
\text { administration }\end{array}$} & \multirow[t]{2}{*}{ Source of data } & \multicolumn{2}{|c|}{$\begin{array}{l}\text { Average plateau plasma levels } \\
\times 10^{5} \mu \mathrm{g} / \mathrm{mll}( \pm \text { S.D.) }\end{array}$} \\
\hline & & & Estrone & Estradiol \\
\hline Estrone & $\begin{array}{l}\text { i.v. }{ }^{b} \\
\text { Vaginal }\end{array}$ & $\begin{array}{l}\text { Figs. } 4 \mathrm{~A} \text { and } 6 \mathrm{~A} \\
\text { Fig. } 6 \mathrm{~B}\end{array}$ & $\begin{array}{l}1.70(0.26) \\
0.82(0.09)\end{array}$ & $\begin{array}{l}1.15(0.14) \\
0.82(0.09)\end{array}$ \\
\hline$\beta$-Estradiol & $\begin{array}{l}\text { i.v. } \\
\text { Vaginal }\end{array}$ & $\begin{array}{l}\text { Figs. } 4 B \text { and } 5 A \\
\text { Fig. 5B }\end{array}$ & $\begin{array}{l}0.60(0.18) \\
0.75(0.09)\end{array}$ & $\begin{array}{l}3.22(0.27) \\
1.23(0.07)\end{array}$ \\
\hline
\end{tabular}

a All infusion rates are $0.21 \mu \mathrm{g} / \mathrm{h}$.

${ }^{b}$ Calculated plateau value includes all data points after $4 \mathrm{~h}$.

c Calculated plateau value includes all data points after $3 \mathrm{~h}$.

34 and 35 will give estimates of the mass transfer rates i f estrone and estradiol from the membrane to the blood. Pursuing this analysis further to assess membrane metabolism following the vaginal administration of estrone or estradiol, one can combine Eqns. 34 and 35 with Eqns. 21 and 31, respectively. Thus, for the vaginal infusion of estrone case, one obtains:

$$
\begin{aligned}
R-K_{6}\left(E_{1}\right)_{m} & =K_{1}\left(E_{1}\right)_{m}-K_{2}\left(E_{2}\right)_{m}+K_{3}\left(E_{1}\right)_{m} \\
& =R-k_{1}\left(E_{1}\right)_{b}+k_{2}\left(E_{2}\right)_{b}-K_{3}\left(E_{1}\right)_{b}
\end{aligned}
$$

For the vaginal infusion of estradiol case, one gets:

$$
\begin{aligned}
R-K_{7}\left(E_{2}\right)_{m} & =-K_{1}\left(E_{1}\right)_{m}+K_{2}\left(E_{2}\right)_{m}+K_{4}\left(E_{2}\right)_{m} \\
& =R+k_{1}\left(E_{1}\right)_{b}-k_{2}\left(E_{2}\right)_{b}-k_{4}\left(E_{2}\right)_{b}
\end{aligned}
$$

The term, $R-K_{6}\left(E_{1}\right)_{m}$, represents the difference in the membrane influx and efflux rates of estrone and the other term, $R-K_{7}\left(E_{2}\right)_{m}$, is the difference between the influx and efflux rates of the estradiol administered.

The division of Eqns. 40 and 41 by $R$ yields:

$$
\begin{aligned}
& 1-\frac{K_{6}\left(E_{1}\right)_{m}}{R}=\begin{array}{l}
\text { fraction of metabolites appearing in blood from vaginal infusion of } \\
\text { estrone }
\end{array} \\
& \frac{\mathrm{K}_{6}\left(\mathrm{E}_{1}\right)_{\mathrm{m}}}{\mathrm{R}}=\begin{array}{c}
\text { fraction of estrone appearing in blood from vaginal infusion of } \\
\text { estrone }
\end{array} \\
& 1-\frac{K_{7}\left(E_{2}\right)_{m}}{R}=\begin{array}{l}
\text { fraction of metabolites appearing in blood from vaginal infusion of } \\
\text { estradiol }
\end{array} \\
& \frac{K_{7}\left(E_{2}\right)_{m}}{R}=\begin{array}{l}
\text { fraction of estradiol appearing in blood from vaginal infusion of } \\
\text { estradiol }
\end{array}
\end{aligned}
$$


TABLE 3

ESTIMATES OF MEMBRANE-TO-BLOOD MASS TRANSFER RATE; AND BIOAVAILABILITY OF ESTROGENS BY ZERO-ORDER VAGINAL INFUSION OF ESTRC NE AND ESTRADIO'

\begin{tabular}{|c|c|c|c|c|c|}
\hline \multirow{2}{*}{$\begin{array}{l}\text { Vaginal } \\
\text { infusion } \\
\text { of }\end{array}$} & \multicolumn{2}{|c|}{$\begin{array}{l}\text { Membrane to blood traiisfer } \\
\text { rate }(\mu \mathrm{g} / \mathrm{h})\end{array}$} & \multicolumn{3}{|c|}{$\begin{array}{l}\text { Fraction of estrogen absorbed by vaginal meinbraric } \\
\text { appearing in bloor as }\end{array}$} \\
\hline & $\mathrm{K}_{6}\left(\mathrm{E}_{1}\right)_{\mathrm{m}}$ & $\mathrm{K}_{7}\left(\mathrm{E}_{2}\right)_{\mathrm{m}}$ & Estrune ${ }^{a}$ & Estradiol $b$ & $\begin{array}{l}\text { Total } \\
\text { conjugates }\end{array}$ \\
\hline Estrone & $9.48 \times 10^{-2}$ & $1.98 \times 10^{-2}$ & 0.45 & 0.09 & 0.46 \\
\hline Estradiol & $7.41 \times 10^{-2}$ & $5.4 \times 10^{-2}$ & 0.35 & 0.26 & 0.39 \\
\hline
\end{tabular}

a Calculated by $\mathrm{K}_{6}\left(\mathrm{E}_{1}\right)_{\mathrm{m}}{ }^{\prime} \mathrm{R}$ where $\mathrm{R}=0.21 \mu \mathrm{g} / \mathrm{h}$.

b Calculated by $\mathrm{K}_{7}\left(\mathrm{E}_{2}\right)_{\mathrm{m}}, \mathrm{R}$.

c Calculated by difference from $100 \%$.

The computation of these bioavailability quantities do not depend upon the a priori knowledge of the metabolic kinetics of estrone and estradiol to their respective conjugates in the membrane and peripheral blood-tissue compartments nor the membrane efflux rates of the conjugates. The summary of calculated parameters and bioavailability is given in Table 3. On the one hand, when estrone is administered vaginally, the membrane-to-blood transfer rate of estrone is $9.48 \times 10^{-2} \mu \mathrm{g} / \mathrm{h} ; 45 \%$ of the estrone absorbed by the membrane appears in the blood unchanged and about $9 \%$ appears in blood as estradiol and $46 \%$ as conjugates. On the other hand, when estradiol is infused, the transfer rate of estradiol is $7.41 \times 10^{-2} \mu \mathrm{g} / \mathrm{h} ; 26 \%$ of the total blood concentration appears in the blood as estradiol and 35 and $39 \%$ as estrone and total conjugates, respectively.

While the above analysis has been based upon data obtained using a single monkey, it should be pointed out that both zero-order intravaginal and zero-order intravenous infusion experiments have been carried out with other monkeys. In all cases the limited data obtained in other monkeys have been consistent with those used in the present analysis.

\section{Further pharmacokinetic analyses}

Additional pharmacokinetic analyses can be made once the plateau values of the total conjugates are known. However, the plateaus were not as evident as those for estrone and estradiol (see Figs. 4-6). Let us use the following estimated plateau levels for the total conjugates:
(A) $=4.8( \pm 0.5) \times 10^{-5} \mu \mathrm{g} / \mathrm{ml}$
(B) $=6.7( \pm 0.5) \times 10^{-5} \mu \mathrm{g} / \mathrm{ml}$
$(\mathrm{G})=6.3( \pm 0.5) \times 10^{-5} \mu \mathrm{g} / \mathrm{ml}$

where the $( \pm 0.5)$ indicates the interval range.

Table 4 gives the apparent systemic elimination constants of the total conjugates of 
TABLE 4

ADDITIONAL ESTIMATES OF PHARMACOKINETIC QUANTITIES

\begin{tabular}{llr}
\hline Vaginal infusion of & Parameters & Values \\
\hline Estrone & $\mathrm{K}_{3}\left(\mathrm{E}_{1}\right)_{\mathrm{m}}$ & $94.2( \pm 0.09) \times 10^{-3} \mu \mathrm{gg} / \mathrm{h}$ \\
& $\mathrm{K}_{4}\left(\mathrm{E}_{2}\right)_{\mathrm{m}}$ & $1.2 \pm 0.09) \times 10^{-3} \mu \mathrm{g} / \mathrm{h}$ \\
& $\mathrm{K}_{1}\left(\mathrm{E}_{1}\right)_{\mathrm{m}}-\mathrm{K}_{2}\left(\mathrm{E}_{2}\right)_{\mathrm{m}}$ & $21 \quad \pm 0.09) \times 10^{-3} \mu \mathrm{g} / \mathrm{h}$ \\
Estradiol & $\mathrm{K}_{3}\left(\mathrm{E}_{1}\right)_{\mathrm{m}}$ & $74.4( \pm 0.1) \times 10^{-3} \mu \mathrm{g} / \mathrm{h}$ \\
& $\mathrm{K}_{4}\left(\mathrm{E}_{2}\right)_{\mathrm{m}}$ & $7.5( \pm 0.1) \times 10^{-3} \mu \mathrm{g} / \mathrm{h}$ \\
& $\mathrm{K}_{2}\left(\mathrm{E}_{2}\right)_{\mathrm{m}}-\mathrm{K}_{1}\left(\mathrm{E}_{1}\right)_{\mathrm{m}}$ & $148.2( \pm 0.1) \times 10^{-3} \mu \mathrm{g} / \mathrm{h}$ \\
Estrone or estradiol & $\mathrm{k}_{\mathrm{e} 1}$ & $5.66 \times 10^{3} \mathrm{~cm}^{3} / \mathrm{h}$ \\
& $\mathrm{k}_{\mathrm{e} 2}$ & $2.71 \times 10^{3} \mathrm{~cm}^{3} / \mathrm{h}$ \\
\hline
\end{tabular}

estradiol and estrone in the blood, $\mathrm{k}_{\mathrm{e} 1}$ and $\mathrm{k}_{\mathrm{e} 2}$, and also vaginal membrane metabolism rates of estrone to estrone conjugates, $\mathrm{K}_{3}\left(\mathrm{E}_{1}\right)_{\mathrm{m}}$, and of estradiol to estradiol conjugates, $\mathrm{K}_{4}\left(\mathrm{E}_{2}\right)_{\mathrm{m}}$, during the vaginal administration of estrone or estradiol. When estradiol is vaginally infused, the net rate of metabolism of estradiol to estrone (i.e. $K_{2}\left(E_{2}\right)_{m}$ $\left.K_{1}\left(E_{1}\right)_{m}\right)$ is $14.82 \times 10^{-2} \mu \mathrm{g} / \mathrm{h}$ and this is about 7 times faster than net rate of membrane metabolism of estrone to estradiol (i.e. $\left.K_{1}\left(E_{1}\right)_{m}-K_{2}\left(E_{2}\right)_{m}\right)$ when estrone is infused at the same zero-order rate. In reviewing the overall results in Table 4, one is led to conclude that the predominant route of membrane metabolism of vaginally infused estrone is conjugation to polar metabolites rather than reduction to estradiol. Furthermore, the dominant metabolic route of vaginally infused estradiol is oxidation to estrone rather than conjugation.

\section{SIGNIFICANCE OF THE PRESENT STUDIES}

The significant features of this study are two-fold. The first is the development of novel experimental and theoretical methodology in assessing the metabolic events affecting the net transport of vaginaliy administered estrone and estradiol across the membrane and into the general blood circulation. The theory and method were demonstrated for estrone and estradiol by obtaining steady-state peripheral blood levels of these steroids and their pooled metabolites resulting from the zero-order infusions of the steroids by the vaginal and intravenous routes. Comparison of the blood levels gave a rapid estimation of overall bioavailability via the vaginal route. Furthermore, by using pharmacokinetic modeling of the steady-state situation, a circumstance in which the vaginal membrane concentrations are in equilibrium with the concentrations in the peripheral blood-tissue compartment, and by using quantitative kinetic parameters derived therefrom, it has been possible to demonstrate that differences in the blood levels from vaginal and intravenous drug infusion mirror the transport and metabolic activities in the membrane in a manner which is believed to be model-independent in the final analysis. In other words, the experimental design and theoretical analysis of the study enables one to uniquely distinguish and quantify first pass metabolic activity in the vaginal membrane from first 
pass liver metabolism and other peripheral tissue metabolism.

The second general contribution of these studies is the quantitative assessment of bioavailability via the vaginal route of administration. Results in the female rhesus monkey are as follows.

(1) Membrane metabolism of infused estrone and estradiol has the effect of reducing the blood levels of these steroids by about 55 and $61 \%$, respectively, of that expected in the absence of membrane metabolism.

(2) About $45 \%$ of vaginally administered estrone appears directly in the b! od as estrone and about 10\% appears as estradiol and about $46 \%$ as total conjugates. The dominant route of membrane metabolism of vaginally infused estrone is conjugation to polar metabolites (sulfate and glucuronide conjugates of estrone) rather than reduction to estradiol.

(3) When estradiol is infused vaginally, $26 \%$ estradiol appears in the blood unchanged, $35 \%$ as estrone and $39 \%$ as total conjugates. Here, the more important metabolic route is oxidation of estradiol to estrone and not conjugation.

(4) The apparent permeability coefficients of estrone and estradiol in the vaginal membrane are rather low, of the order of about $1 \times 10^{-4} \mathrm{~cm} / \mathrm{s}$.

From the viewpoint of possible clinical importance, $55 \%$ of the estrone absorbed by the membrane exist in the form of two therapeutically active estrogens (45\% estrone and $10 \%$ estradiol). Interestingly, vaginally infused estradiol appears directly in the blood to the extent of about $61 \%$ total active estrogens (almost equal fractions of estradiol and estrone). While the results of this study show that membrane has fairly high metabolic activity for estrone and estradiol, the vaginal administration of natural contraceptive estrogens may yet prove to be the more reliable therapeutic route as compared to oral administration since the bioavailable steroidal species entering the circulatory system are distributed throughout the body tissues prior to metabolism in the liver. Since the female rhesus monkey is believed to be a good model of the human, the results of this study may be of direct clinical significance and may provide a good estimation of the bioavailability of natural contraceptive estrogens in the human female by vaginal administration. The results of this study are in general agreement with the recent blood level studies of vaginally administered $\beta$ estradiol and estrone suspensions in humans by Schiff et al. (1977) and Rigg et al. (1977).

\section{REFERENCES}

Barr, W.H. and Riegelman, S., Intestinal drug absorption and metabolism II: Kinetic aspects of intestinal glucuronide conjugation. J. Pharm. Sci., 59 (1970) 164-168.

Carrington, G.L., Rohrer, T., Jones, E. and Moore, P., Sulfanilamide absorption via the rectum and vagina. Surg. Gynecol. Obstet., 78 (1944) 333-334.

Diczfalusy, E., Franksson, C. and Martinsen, B., Oestrogen conjugation by the human intestinal tract. Acta Endocr., 38 (1961) 59-72.

Diczfalusy, E., Franksson, C., Lisboa, B.P. and Martinsen. B., Formation of oestrone glucosiduronate by the human intestinal tract. Acta Endocr., 40 (1962) 537-551.

Flynn, G.L., Ho, N.F.H., Hwang, S., Owada, E., Molokhia, A.M., Behl, C.R., Higuchi, W.I., Yotsuyanagi, T., Shah, Y. and Park, J., Interfacing matrix release and membrane absorptionanalysis of steroid absorption from a vaginal device in the rabbit doe. In Paul, D.R. and Harris, 
F.W. (Eds.) ACS Symposium Series, No. 33, Controlled Release Polymeric Formulations, 1976, pp. 87-122.

Fried, N.D., Tredway, D.R. and Mishell, D.R., Jr., Termination of early pre gnancy with prostaglandin $E_{2}$ vaginal suppositores. Contraception, 8 (1973) 255-263.

Goldberger, M.A.s Walter, R.I. and Lapid, L.S., Absorption of penicillin from the vagina. Am. J. Obstet. Gynecol., 53 (1947) 529-531.

Howard, C.M., Robinson, H., Schmidt, F.H., McCord, J.R. and Preedy, J.R.K., Evidence for a two pool system governing the excretion of radioactive urinary estrogen conjugates during the first eight hours following the administration of estrone $-6,7-{ }^{3} \mathrm{H}$ to male subjects. Probable role of the enterohepatic circulation. J. Clin. Endocr. Metab., 29 (1969) 1618-i629.

Hwang, S., Owada, E., Yotsuyanagi, T., Suhardja, L., Ho, N.F.H., Flynn, G.L. and Higuchi, W.I., Systems approach to vaginal delivery of drugs II. In situ vaginal absorption of unbranched aliphatic alcohols. J. Pharm. Sci., 65 (1976) 1574-1578.

Hwang, S., Owada, E., Suhardja, L., Ho, N.F.H., Flynn, G.L. and Higuchi, W.I., Systems approach to vaginal delivery of drugs V. In situ vaginal absorption of 1-alkanoic acids. J. Pharm. Sci., 66 (1977) $781-784$.

Johansson, E.D.B., Luukkainen, T., Vartiainen, E. and Victor, A., The effect of progestin R 2323 released from vaginal rings on ovarian function. Contraception, 12 (1975) 299-307.

Kirton, K.T., Roseman, T.J. and Forber, A.D., Evaluation of progesterone-containing silicone vaginal devices in rhesus monkeys. Contraception, 8 (1973) 561-568.

Meli, A., Cargill, D.I., Giannina, T. and Steinetz, B.G., Studies on the transport of estrogens by the rat small intestine in vivo (33463). Proc. Soc. Exptl. Biol. Med., 129 (1968) 93.7-944.

Migeon, C.J., Wall, P.E. and Bertrand, J., Some aspects of the metabolism of $16-{ }^{14} \mathrm{C}$ estrone in normal individuals. J. Clin. Invest., 38 (1959) 619-629.

Mishell, D.R., Jr., Lumkin, M. and Stone, S., Inhibition of ovulation with cyclic use of progestogenimpregnated intravaginal devices. Am. J. Obstet. Gynecol., 113 (1972) 927-932.

Nienstedt, W. and Hartiala, K., Steroid metabolism by the canine intestine. I. Qualitative experiments with progesterone. Scand. J. Gastroent., 4 (1969) 483-488.

Nuwayser, E.S. and Williams, D.L., Development of a delivery system for prostaglandins. Adv. Exptl. Med. Biol., 47 (1974) 145-164.

Owada, E., Behl, C., Hwang, S., Suhardja, L., Glynn, G.L., Ho, N.F.H. and Higuchi, W.I., Vaginal drug absorption in rhesus monkeys I: Development of methodology. J. Pharm. Sci., 66 (1977) 216219.

Pang, K.S. and Gillette, J.R., Theoretical relationships between area under the curve and route of administration of drugs and their precursors for evaluating sites and pathways of metabolism. $J$. Pharm. Sci., 67 (1978) 703-704.

Rigg., L.A., Milanes, B., Villanueva, B. and Yen, S.S.C., Efficacy of it travaginal and intranasal administration of micronized estradiol-17ß. J. Clin. Endocr. Metab., 45 (4977) 1261-1264.

Schiff, I., Tulchinsky, D. and Ryan, K.J., Vaginal absorption of sstrone and 17ßestradiol. Fertil. Steril., 28 (1977) 1063-1066.

Smith, F.R., Tapley, D.F. and Ross, J.E., Glucuronide formation in the transport of estradiol by rat intestine in vitro. Biochim. Biophys. Acta, 69 (1963).

Stone, G.M. and Martin, L., Radioactive compounds in the vagina of the ovariectomized mouse after local application of oestradiol $6,7 \cdot{ }^{3} \mathrm{H}$ and oestrone-6,7- ${ }^{3} \mathrm{H}$. Steroids: 5 (1965) $791-807$.

Strahl, N.R. and Barr, W.I., Intestinal drug absorption and metabolism III: Glycine conjugation and accumulation of benzoic acid in rat intestinal tissue. J. Pharm. Sci., 60 (1971) 278-281 .

Touchstone, J.C., Murawec, T. and Brual, O., Improved solvent systems for thin layer chromatography of estrogens. J. Chromatogr., 37 (1968) 361-362.

Yotsuyanagi, T., Molokhia, A., Hwang, S., Ho, N.F.H., Flynn, G.d. and Higuchi, W.I., Systems approach to vaginal delivery of drugs $I$. Development of in situ vaginal drug absorption procedure. J. Pharm. Sci., 64 (1975) 71-76. 